\title{
The Relationship Between Money Supply, Interest Rate and Inflation Rate: an Endogeneity-Exogeneity Approach
}

\author{
Fatih Kaplan \\ Mersin University, School of Applied Technology and Management of \\ Tarsus, Department of International Trade and Logistics, Turkey

\section{Sule Gungor} \\ Mersin University, Vocational School of Tarsus, \\ Department of Accounting and Tax, Turkey
}

\section{doi: 10.19044/esj.2017.v13n1p30 ～URL:http://dx.doi.org/10.19044/esj.2017.v13n1p30}

\begin{abstract}
After the 2008 Financial Crisis, The Central Bank is Turkey as well as many countries, has implemented a policy of increasing the money supply. It is a known fact that the changes in the money supply are considerable extent determinative in interest rate and inflation rate such as orientations of macro economics variables. The purpose of this study is to investigate the relationship between money supply, interest rate and inflation rate in Turkey after the 2008 Financial Crisis. In accordance with this purpose, 2008:12015:12 period money supply, interest rate and inflation rate monthly data are used. Commonly in applied studies, the relationship between these variables is analysed with Cholesky Decomposition Method of Variance based Vector Autoregression Model (VAR). But this method is affected by ordering of the variables according to endogeneity-exogeneity approach, when ordering of the variables were changed, the results are changed and therefore policy proposals are changed. In analysis of the study, both Cholesky and Pesaran and Shin's proposal method is used. According to Cholesky Variance Decomposition result at the end of the a month, when all changes in inflation is explained by inflation, this rate is $85 \%$ according to Generalized Decomposition Method of Variance result.
\end{abstract}

Keywords: Money Supply, Interest Rate, Inflation Rate, EndogeneityExogeneity, Time Series Analysis

\section{Introduction}

The essay titled "Of Money" published by David Hume in 1752 is considered as the basis of today's various monetary theories (Paganelli, 2006). 
In this essay, Hume explains his theory known as "Beneficial Inflation Theory" and asserts that increasing money supply does not only raise prices but also boosts economic activities. In his other essay titled " Of Interest", Hume suggests that increasing money supply will raise all prices and thereby money demand, and for this reason interest rate will not change . In his essays, Hume discusses about the impact of money supply on inflation and interest rate and leads the way to discussions of numerous economists about the relations between money supply, inflation and interest rates up to day.

After 2008 Financial Crisis, Turkey applied the policy of expanding money supply as done by many countries. Changes in money supply effects the direction of some macro-economic variables such as interest rate and inflation rate. For predicting the consequences of policies to be applied, first of all it must be distinguished whether the relation between these variables are endogenous or exogenous. Pursuant to endogeneity and exogeneity distinction, the variable for which the value is determined within the model is called endogenous variable, and the variable for which the value is determined outside the model is called exogenous variable. While this distinction can be easily made with a priori knowledge for some variables, it is hard to make this distinction for some other variables (Kaplan and Aktas, 2012). For instance, in cases where money supply is increased by Central Banks exogenously, increasing money supply may lead to inflationary expectations and thereby increasing interests may either increase or decrease interest rate for increasing money supply. While money supply can influence interest rate generation at real level, interest rate generation may change with the influence of account owners, entrepreneurs and political lobbies as well. This means that interest rate generation can be endogenous as much as it is exogenous (Snowdon and Vane, 2005). In the light of a priori knowledge, if endogeneity or exogeneity distinction can not be made for the variable, statistical tests or analyses that do not require endogeneity or exogeneity distinction can be leveraged.

Unlike previous studies, this study focuses on theoretical framework regarding how the relevant variables can be placed in the model. As a result of this theoretical framework, generalized variance decomposition method, suggested by Pesaran and Shin (1998), is used in relation analysis as it complies with the theory. In applied studies, the relation between these variables are generally analyzed with VAR model based Cholesky Variance Decomposition method. In VAR models, variables are sorted from exogenous to endogeneous. However, this method is effected by the fact that variables are sorted according to their endogeneity or exogeneity, results change as sorting of variables change and thereby policy suggestions change as well. For this reason, we used the method suggested by Pesaran and Shin (1998), which provides results consistent with the sorting of variables based on variance distinction. 
The aim of this study is to test the relation between money supply, inflation and interest rates with generalized Variance Decomposition Method. In the second part of this study, the general theory of money supply is discussed within the scope of endogeneity-exogeneity, and it is analyzed how money supply's inflation and interest rates are handled by the schools of economics with endogeneity-exogeneity approach. In the third part of this study, the data and method used in the study are introduced and the results of econometric analysis are interpreted. In the conclusion part, brief evaluations are presented.

\section{Theoretical Framework}

The way how money supply affects other variables in a model including money supply variable (especially when the relation between inflation and interest rate is discussed) is a frequently discussed topic. For this reason, the knowledge whether money supply is exogenous or endogeneous will function as a priori knowledge regarding how it will be included in the model. However the fact that Central Banks have monopoly in printing money means that they can control money supply and supports the idea that money supply is exogeneous, loan extension processes by the banks resolve full control power of Central Banks and makes the idea that money supply is endogeneous reasonable. However, according to Desai (1989), endogeneity or exogeneity of money is largely due to the fact that the currency economy is commodity money, paper money, credit (liquid) money, and also depends on the extent of banking and the financial system used.

Exogenous money supply idea depends on the amount of money theory which is the basic foundation of New Classical Economics and Money Doctrine. The amount of money theory assumes that Central Bank has the capacity to lend money through rebate and to identify money supply through dynamic open market operations on its own (Pollin, 2008). Endogenous money supply idea was suggested by Post-Keynesians during the 1970s in which money doctrine was most discussed about. Post-Keynesian monetary theory rejects exogenous money concept and the assumption of Classical Macroeconomists and Neo-Keynesians that money supply is exogenous (Palley, 2002).

The basis of endogenous money supply idea is that money stock in a country is identified by the causal dependence on banks' loan demands and economic variables that affect production level (Fontana, 2003). According to Pally (2002), pursuant to endogeneity; full endogeneity, structural endogeneity and liquidity endogeneity approaches become prominent in literature although there are various approaches such as evolutionary endogenous money, endogeneity of the Central Bank, financial endogeneity, money multiplier-portfolio endogeneity, loan money endogeneity, supply side 
financial instruments endogeneity, cyclical money endogeneity and open economy endogeneity.

Economists defending endogeneity of money supply are split in opinion regarding how interest rates are determined in endogeneity. Structural endogeneity and liquidity preference approach suggest that interest rate is determined endogenously like money supply while interest rates are determined by the Central Bank exogenously according to defenders of full endogeneity (Nell, 1999). If we assume that money supply is endogenous, Central Bank is not the sole authority in the identification of neither money supply nor interest rate. According to Fiedman, while the amount of money is under the control of money authorities, interest rate may differ with the development of monetary transactions irrespective of the demands of authorities (Mankiw, 2014).

Regarding exogeneity of money supply, Central Bank determines interest rate (exogenously) initially, but it is not supposed to meet subsequent reserve demand "passively" (Wray, 2004). This idea was criticized from two aspects: First of all, this view is not different from the explanations of policy preferences between the interest rates of the established economy or the targeting of reserves. In this respect, if the Central Bank prefers to target interest rates, it loses its control over the reserves. However, if it will prefer to hold reserve targets and thereby monetary targets. Therefore, the control over the interest rate will be lost and the interest rate will be determined internally by the market. The second criticism is that the Central Bank has to meet the demand for reserves after determining the interest rate externally. According to Wray, the flexibility of reserve requirements is very low because the private sector can not increase its supply, and thereby the interest rates will be rather unstable without the Central Bank's adaptation. Even so, Central Banks' compliance will cause interest rates to change, depending on risk perceptions (Wray, 2004).

There is no consensus on the endogenous or exogenous impact of money supply on the inflation, as it is the case in interest rates. Discussions in this area focus on the New Keynesian Phillips Curve. Kiley (2002) argues that money supply exogenous affects inflation, while Seidel (2005) suggests that money supply has an endogenous effect on inflation.

Considering the relevant theoretical framework, it is seen that there is no consensus among the economics schools regarding endogeneityexogeneity relation between the money supply, the interest rate and the inflation rate. Therefore, it is necessary to consider the relationship between these variables without making endogeneity-exogeneity distinction. 


\section{Data, Methodology and Results}

The aim of this study is to test the relation between money supply, inflation rate and interest rates with generalized Variance Decomposition Method. Monthly data for the period of 2008: 1-2015: 12 were used for this purpose. The reason for the use of the period 2008-2015 is the fact that the money supply was also increased in Turkey as in many countries in this period. The money supply has a critical importance for inflation and interest rates.

In the study, for the money supply (M1), the money supply of the Central Bank of the Republic of Turkey, defined as M1, was used. For the inflation rate (INF), the consumer price index (CPI) values based on 2005 are used. INF is calculated with the aid of the formula [(CPI Index - CPI Index 1) / (CPI Index - 1)* 100)] considering CPI. For the interest rate (I), the overnight borrowing interest rates in the interbank market are used. Monthly real interest rates are calculated by using the formula of real interest $=[[(1+$ interest rate $) /(1+$ inflation rate $)]-1]$ x 100 after the monthly average of overnight borrowing interest rates is taken. The series of all variables are taken from the Electronic Data Distribution System (EVDS) of the Central Bank of the Republic of Turkey. As a result of the seasonality analysis, it was decided that no series had strong seasonality characteristics and the series were used in the forecasts without any filtering.

For the Generalized Variance Decomposition, it is necessary to calculate the Generalized Impact Response Functions. For this reason, VAR analysis is carried out in the study. In the VAR analysis, the stationary states of the series should be used. Therefore, the unit root test was performed primarily on the series. The existence of unit root within the series was researched by using ADF Test (Augmented Dickey Fuller, 1981) developed by David A., Dickey and Wayne A.Fuller; P-P Test (1988) developed by B. Phillips and Pierre Perron and Dickey-Fuller based DF-GLS Test developed by Graham Elliot, Thomas J. Rothenberg and James H. Stock (1996).

In the VAR analysis, Akaike, Schwarz (SC), Hannan-Quinn (HQ) and Maximum Likelihood (LR) information criteria were used in selecting appropriate delay lengths of variables. In the Unrestricted VAR model, a twoterm lagged model was selected between the 12-month delay due to the monthly series, in which the characteristic roots of the system stay within the unit circle and provide stability condition, and autocorrelation and heteroscedasticity problems do not happen in error terms.

The generalized impulse response functions, proposed by Pesaran and Shin (1998) by considering the Unrestricted VAR model, were analyzed by generalized variance decomposition analysis, which is calculated from the generalized impulse response functions. While the Cholesky decomposition, which is the conventional method of predicting impulse response functions, may show different results depending on the order of the variables, the analysis 
results in the method proposed by Pesaran and Shin are independent of the model input order of the variables. You can find the results of unit tests on Table 1.

Tablo 1.Unit Root Test Results

\begin{tabular}{|c|c|c|c|c|c|c|c|}
\hline Test & Model & $\mathrm{ADF}$ & PP & $\begin{array}{l}\text { DF- } \\
\text { GLS }\end{array}$ & $\Delta \mathrm{ADF}$ & $\Delta \mathrm{PP}$ & $\begin{array}{l}\Delta \mathrm{DF}- \\
\text { GLS }\end{array}$ \\
\hline \multirow{2}{*}{ M1 } & Constant & $\begin{array}{c}-0.44 \\
(1)\end{array}$ & $\begin{array}{c}-0.22 \\
(3)\end{array}$ & $\begin{array}{c}3.01^{*} \\
(1)\end{array}$ & $\begin{array}{c}-14.30^{*} \\
(0)\end{array}$ & $\begin{array}{c}-14.43 * \\
(4)\end{array}$ & $\begin{array}{c}-1.73^{* *} \\
\text { (3) }\end{array}$ \\
\hline & $\begin{array}{c}\text { Constant } \\
\text { Trend }\end{array}$ & $\begin{array}{c}-2.48 \\
(1)\end{array}$ & $\begin{array}{c}-3.84 * * \\
(5)\end{array}$ & $\begin{array}{c}-2.51 * * \\
(1)\end{array}$ & $\begin{array}{c}-14.22 * \\
(0)\end{array}$ & $\begin{array}{c}-14.33 * \\
(4)\end{array}$ & $\begin{array}{c}-11.97 * \\
(0)\end{array}$ \\
\hline \multirow{2}{*}{ INF } & Constant & $\begin{array}{c}-3.41 * * \\
(1)\end{array}$ & $\begin{array}{c}-3.27 * * \\
(3)\end{array}$ & $\begin{array}{c}-2.01 * * \\
(0)\end{array}$ & $\begin{array}{c}-7.61 * \\
(0)\end{array}$ & $\begin{array}{c}-7.61 * \\
(0)\end{array}$ & $\begin{array}{c}-7.05^{*} \\
(0)\end{array}$ \\
\hline & $\begin{array}{c}\text { Constant } \\
\text { Trend }\end{array}$ & $\begin{array}{c}-3.65 * * \\
(1) \\
\end{array}$ & $\begin{array}{c}-3.46^{* *} \\
(3) \\
\end{array}$ & $\begin{array}{c}-2.90^{*} \\
(1) \\
\end{array}$ & $\begin{array}{c}-7.59 * \\
(0)\end{array}$ & $\begin{array}{c}-7.59 * \\
(0)\end{array}$ & $\begin{array}{c}-7.49 * \\
(0)\end{array}$ \\
\hline \multirow{2}{*}{ I } & Constant & $\begin{array}{c}-2.29 \\
(0)\end{array}$ & $\begin{array}{c}-2.29 \\
(0)\end{array}$ & $\begin{array}{c}-0.94 \\
(0)\end{array}$ & $\begin{array}{c}-9.70^{*} \\
(0)\end{array}$ & $\begin{array}{c}-9.70^{*} \\
(0)\end{array}$ & $\begin{array}{c}-7.24^{*} \\
(0)\end{array}$ \\
\hline & $\begin{array}{c}\text { Constant } \\
\text { Trend }\end{array}$ & $\begin{array}{c}-1.97 \\
(0) \\
\end{array}$ & $\begin{array}{c}-1.93 \\
(1) \\
\end{array}$ & $\begin{array}{c}-1.35 \\
(0)\end{array}$ & $\begin{array}{c}-9.82 * \\
(0)\end{array}$ & $\begin{array}{c}-9.84 * \\
(2)\end{array}$ & $\begin{array}{c}-9.38^{*} \\
(0)\end{array}$ \\
\hline
\end{tabular}

Note: $*, * *$ and $* * *$ indicate the level of significance of $1 \%, 5 \%$ and $10 \%$, respectively, and

$" \Delta "$ is the first difference operator. The maximum lagged length was taken as 12 and the

Schwarz (1978) information criterion was used to determine the optimal lagged length.

While determining the optimal lagged length, it is also taken into account that there are no autocorrelation problems in error terms. In the PP test, the "Barlett-Kernel Method" and the bandwidth "Newey West Bandwith Method" were used.

As a result of the unit root tests made, it is seen that the inflation variable does not contain unit roots at the level of the variable. Money supply and interest rate variables have unit root at their levels in both constant and constant trend models. When the difference taking process was performed from the first level, it is determined that the money supply and interest rate variables do not contain unit root in constant and constant trend models.

The results of Unrestricted VAR model, which is based on the unit root test results, are given in Table 2 below.

Table 2. Variance Decomposition

\begin{tabular}{c|c|c|c|c|c|c|c|c|c}
\hline \multirow{2}{*}{ Period } & \multicolumn{8}{|c}{ Cholesky Variance Decomposition } \\
\cline { 2 - 10 } & \multicolumn{3}{|c|}{ M1 } & \multicolumn{3}{c}{ INF } & \multicolumn{3}{c}{ I } \\
\cline { 2 - 10 } & INF & I & M1 & INF & I & M1 & INF & I & M1 \\
\hline 1 & 0.004 & 2.445 & 97.549 & 100.000 & 0.000 & 0.000 & 17.259 & 82.740 & 0.000 \\
\hline 2 & 5.487 & 3.784 & 90.727 & 96.347 & 2.587 & 1.064 & 18.339 & 81.461 & 0.198 \\
\hline 3 & 5.498 & 4.368 & 90.132 & 92.174 & 4.289 & 3.535 & 21.244 & 78.534 & 0.220 \\
\hline 4 & 5.455 & 4.371 & 90.173 & 91.428 & 4.680 & 3.890 & 22.516 & 76.814 & 0.669 \\
\hline 5 & 5.488 & 4.407 & 90.103 & 90.915 & 4.945 & 4.139 & 23.589 & 75.669 & 0.740 \\
\hline 6 & 5.496 & 4.418 & 90.084 & 90.588 & 5.085 & 4.325 & 24.140 & 75.084 & 0.774 \\
\hline 7 & 5.496 & 4.418 & 90.084 & 90.482 & 5.136 & 4.380 & 24.371 & 74.803 & 0.824 \\
\hline 8 & 5.496 & 4.419 & 90.083 & 90.428 & 5.162 & 4.408 & 24.486 & 74.676 & 0.837 \\
\hline 9 & 5.497 & 4.419 & 90.082 & 90.404 & 5.173 & 4.422 & 24.532 & 74.623 & 0.843 \\
\hline 10 & 5.497 & 4.419 & 90.082 & 90.396 & 5.176 & 4.426 & 24.550 & 74.602 & 0.847 \\
\hline
\end{tabular}




\begin{tabular}{c|c|c|c|c|c|c|c|c|c}
11 & 0.004 & 2.445 & 97.549 & 100.000 & 0.000 & 0.000 & 17.259 & 82.740 & 0.000 \\
\hline 12 & 5.487 & 3.784 & 90.727 & 96.347 & 2.587 & 1.064 & 18.339 & 81.461 & 0.198 \\
\hline \multirow{8}{*}{ Period } & \multicolumn{8}{|c|}{ Geralized Variance Decomposition } \\
\cline { 2 - 10 } & \multicolumn{7}{|c|}{ M1 } & \multicolumn{7}{c}{ INF } & & \multicolumn{3}{c}{ I } \\
\cline { 2 - 10 } & INF & I & M1 & INF & I & M1 & INF & I & M1 \\
\hline 1 & 0.004 & 1.904 & 98.090 & 85.277 & 14.718 & 0.004 & 14.479 & 83.891 & 1.628 \\
\hline 2 & 5.184 & 6.142 & 88.673 & 88.978 & 9.410 & 1.611 & 15.283 & 82.822 & 1.894 \\
\hline 3 & 5.185 & 6.723 & 88.091 & 88.035 & 7.239 & 4.725 & 17.677 & 80.470 & 1.852 \\
\hline 4 & 5.144 & 6.703 & 88.152 & 88.202 & 6.543 & 5.253 & 18.860 & 78.824 & 2.315 \\
\hline 5 & 5.174 & 6.763 & 88.062 & 88.179 & 6.208 & 5.612 & 19.815 & 77.801 & 2.382 \\
\hline 6 & 5.181 & 6.780 & 88.038 & 88.085 & 6.050 & 5.863 & 20.310 & 77.273 & 2.415 \\
\hline 7 & 5.181 & 6.780 & 88.038 & 88.070 & 5.988 & 5.941 & 20.522 & 77.010 & 2.466 \\
\hline 8 & 5.180 & 6.780 & 88.038 & 88.057 & 5.961 & 5.980 & 20.626 & 76.893 & 2.479 \\
\hline 9 & 5.181 & 6.781 & 88.037 & 88.050 & 5.950 & 5.999 & 20.669 & 76.845 & 2.485 \\
\hline 10 & 5.181 & 6.781 & 88.036 & 88.048 & 5.946 & 6.005 & 20.685 & 76.825 & 2.489 \\
\hline 11 & 5.181 & 6.781 & 88.036 & 88.047 & 5.945 & 6.007 & 20.691 & 76.817 & 2.490 \\
\hline 12 & 5.181 & 6.781 & 88.036 & 88.046 & 5.944 & 6.008 & 20.694 & 76.815 & 2.490 \\
\hline & & & & & & & \\
\hline
\end{tabular}

As Cholesky Variance Decomposition result shows, the reason for the change in money supply is money supply $(97.5 \%)$ at the end of the first month whereas the reason for the change in inflation rate will be $100 \%$ inflation rate and the change in interest rate will be due to interest rate (82.7\%). At the end of 12 months a change in money supply will take place; (90.7\%) of this change is explained by the money supply whereas $(3.7 \%)$ of it is expressed by the interest rate and $(5.4 \%)$ of it by the inflation rate. After a change occurs in the rate of inflation; (96.3\%) of this change is explained by inflation rate while $(1 \%)$ of it is explained by money supply and $(2.5 \%)$ of it is explained by interest rate at the end of 12 months. After a change occurs in the interest rate; $(81.4 \%)$ of this change is explained by interest rate while $(18.3 \%)$ of it is explained by inflation rate and $(2.5 \%)$ of it is explained by money supply at the end of 12 months.

According to the result of Generalized Variance Decision, the change in money supply at the end of the first month is found to be (98\%) due to the change in money supply while (85\%) of the change in inflation and interest rates is explained by themselves. At the end of 12 months, after a change occurs in money supply; while (88\%) of this change is explained by the money supply, $(6.7 \%)$ is explained by the interest rate and $5.18 \%$ is explained by the inflation rate At the end of 12 months, after a change occurs in the inflation rate; $(88 \%)$ of this change is explained by inflation rate, $(6 \%)$ is explained by money supply and (5.9\%) is explained by interest rate. At the end of 12 months, after a change occurs in interest rate, $(76.8 \%)$ of this change is explained by the interest rate, $(20 \%)$ is explained by the inflation rate and $(2.4 \%)$ is explained by the money supply. 


\section{Conclusion}

In this study, the relationship between money supply, interest rate and inflation rate in Turkey after 2008 Financial Crisis was investigated by using monthly data of 2008: 1-2015: 12 period. Unlike the previous studies, the theoretical framework about how the relevant variables should be included in the model is discussed. In the analysis of the relation, analyzes were made using the generalized variance decomposition method and the Cholesky variance decomposition method proposed by Pesaran and Shin (1998), which are suitable for the theories, and the results of the analyzes were compared and the results were found to be different.

Two important points stand out from the results of the study. First of all, the money supply, interest rate and inflation rate variables frequently used in macroeconomic analysis must be taken into account in relation to each other both theoretically and practically. Secondly, it is necessary to use the Generalized Variance Analysis in studies using macroeconomic variables in particular instead of the Variance Decomposition Analysis.

\section{References:}

1. Desai, M. (1989). Endogenous and Exogenous Money. in The New Palgrave: Money (pp. 146-150). New York, NY: Macmillan.

2. Dickey, D.A. \& Fuller, W.A., (1981) . Distribution Of The Estimators For Autoregressive Time Series With A Unit Root, Econometrica 49, 1057-1072.

3. Elliott, G., Rothenberg,T.J. \& Stock,J.H.(1996). Efficient Tests For An Autoregressive Unit Root, Econometrica 64, 813-836.

4. Fontana G. (2003). Post Keynesian Approaches To Endogenous Money: A Time Framework Explanation, Review of Political Economy, 15(3) : 291-314.

5. Kaplan, F. \& Aktas, A. R. (2012). Dissallık ve Nedensellik Kavramlari Uzerine Kisa Bir Bakis. [ A Short Overview on the Concepts of Externality and Causality] Uluslararasi Alanya Isletme Fakultesi Dergisi [International Journal of Alanya Faculty of Business] 4(3): 29-34.

6. Kiley, M. T. (2002). Partial Adjustment and Staggered Price Setting. Journal of Money, Credit, and Banking, 34(2): 283-298.

7. Mankiew, G. (2014). Brief principles of Macroeconomics. SouthWeatern Cengage Learning.

8. Nell S. K. (1999). The Endogenous/Exogenous Nature of South Africa's Money Supply Under Direct and Indirect Monetary Control Measures, University of Kent, series of Studies in Economics, Number: 9912. 
9. Palley I. T. (2002). Endogenous Money: What it is and Why it Matters, Metroeconomica, 53: 155-170.

10. Paganelli, M.P. 2006. David Hume and Endogenous Money, Eastern Economic Journal, 32(3): 533-547.

11. Pesaran, H.M., \& Y. Shin 1998. Generalized Impulse Response Analysis in Linear Multivariate Models, Economics Letters 58: 17-29.

12. Phillips, P. C. B., \& Perron, P. (1988). Testing for unit root in time series regression. Biometrica, 75:335-346.

13. Pollin, R.(2008). Considerations on Interest Rate Exogeneity. Political Economy Research Institute.

14. Seidel, G. (2005). Endogenous Inflation : The Role Of Expectations And Strategic Interaction, Sonderforschungsbereich 504 paper,: no. 05-14.

15. Snowdon, B. \& Vane, H. (2005) Modern Macroeconomics: Its Origins, Development And Current State, Edward Elgar Publishing, England.

16. Wray L. R. (2004). When Are Interest Rates Exogenous?, Paper For A Conference in Honor Of Basil Moore: Complexity, Endogenous Money, and Exogenous Interest Rates. 